\title{
PENGARUH KUALITAS LAYANAN TERHADAP KEPUASAN DAN LOYALITAS PELANGGAN HOTEL BUJET DI BANDUNG
}

\author{
Bobby Rozano ${ }^{1}$ \\ STIEPAR YAPARI BANDUNG \\ Bobby.rozano@yahoo.com \\ PanjiPanjiPamungkas ${ }^{2}$ \\ STIEPAR YAPARI BANDUNG \\ panji.pamungkas@yahoo.com
}

\begin{abstract}
ABSTRAK
Hotel bujet di Bandung berkembang pesat dan menjadi satu pilihan untuk tempat menginap. Persaingan yang semakin ketat antar hotel, maka kualitas layanan hotel bujet harus ditingkatkan lebih optimal agar pelanggan puas dan loyal. Tujuan dari penelitian ini adalah untuk mengetahui pengaruh langsung kualitas layanan, tanggapan nilai dan harapan pelanggan terhadap kepuasan dan tidak langsung tehadap loyalitas pelanggan hotel bujet di Bandung. Responden dalam penelitian ini adalah 200 tamu hotel bujet di Bandung dengan teknik pengambilan sampel yang disebut random sampling. Penelitian ini menggunakan analisis jalut dengan bantuan program IBM SPSS 21.

Hasil penelitian ini menunjukkan bahwa : 1) kualitas layanan berpengaruh positif, langsung dan signifikan terhadap kepuasan pelanggan, 2) tanggapan nilai berpengaruh positif, langsung dan signifikan terhadap kepuasan pelanggan, 3) harapan pelanggan berpengaruh positif, langsung dan signifikan terhadap kepuasan pelanggan, 4) kualitas layanan berpengaruh positif, langsung dan signifikan terhadap loyalitas pelanggan. Selain itu ada pengaruh tidak langsung kualitas layanan, tanggapan nilai dan harapan pelanggan melalui variabel kepuasan pelanggan.
\end{abstract}

Kata Kunci: Kualitass layanan, Tatnggapan nilai, Harapan pelanggan, Kepuasan pelanggan dan Loyalitas Pelanggan.

\section{THE INFLUENCE OF QUALITY TOWARDS CUSTOMERS SATISFACTION AND LOYALTY AT BUDGET HOTELS IN BANDUNG}

\begin{abstract}
Budget hotels are growing rapidly in Bandung and becoming an option as a place to stay. The tightness of competition among budget hotels, they should improve the quality of service, customer satisfaction and customer loyalty. The aim of this research is to find out of the effect of service quality, perceived value, customer expectation toward customer satisfaction and customer loyalty of budget hotel in
\end{abstract}


Bandung. The respondent of this research are 200 guest of budget hotel in Bandung, using sampling technique which is called purposive sampling. This research used Path Analysis with IBM SPSS 21.

The result of this research showed that: 1) service quality has direct, positive and significant effect toward customer satisfaction, 2) perceived value has direct, positive and significant effect toward customer satisfaction, 3) customer expectation has direct, positive and significant effect toward customer satisfaction, 4) service quality has direct effect, positive and significant effect toward customer loyalty.

Other results that service quality, perceived value, customer expectation has direct, positive and significant effect toward customer loyalty through customer satisfaction

Keywords: Kualitas layanan, Tanggapan nilai,Harapan pelanggan, Kepuasan pelanggan, dan Loyalitas pelanggan.

\section{PENDAHULUAN}

Industri pariwisata saat ini meningkat secara signifikan seiring berkembangnya pariwisata di Bandung. Berdasarkan data Badan Pusat Statistik kota Bandung, wisatawan ke Bandung meningkat dari tahun ke tahun. Sektor pariwisata berperan dalam meningkatkan Pendapatan Asli Daerah kota Bandung, sehingga pemerintah kota Bandung berkepentingan dan sangat mendukung sektor pariwisata, industri pariwisata dan pelakunya.

Pelaku industri pariwisata diantaranya yaitu sektor akomodasi, transportasi udara, darat, agen travel perjalanan, restoran dan penyedia atraksi wisata. Konsekuensi dari berkembangnya pariwisata pelaku usaha pariwisata harus menyesuaikan dan mengembangkan diri terhadap perubahan yang terjadi.

Salah satu pelaku pariwisata yaitu hotel yang tersedia di Bandung terdiri dari non bintang, apartemen hingga hotel mewah bintang 5. Jenis hotel yang berkembang pesat di kota Bandung adalah hotel bujet. Pembangunan hotel bujet di Bandung dalam 5 tahun terakhir meningkat. Hotel bujet adalah salah satu jenis hotel yang dikategorikan hotel bintang 2 yang dikenal sebagai tempat yang nyaman, ekonomis dan tempat yang dekat kota. Hotel bujet semakin tren karena tingkat okupansi yang tinggi, praktis, efisien, kamar cukup beukuran $16 \mathrm{~m}^{2}$, twin atu single bed, toilet dan kamar mandi dengan shower, AC, TV kabel dan jaringan internet dengan biaya terjangkau kisaran Rp. 300.000,-/hari

Perkembangan hotel bujet di Bandung ditunjukkan pada gambar 1 untuk memenuhi kebutuhan akan akomodasi dari wisatawan ataupun pengguna lain menunjukkan kecenderungan naik dengan pertumbuhan 25,19\% dari 2009 ke tahun 2013. 


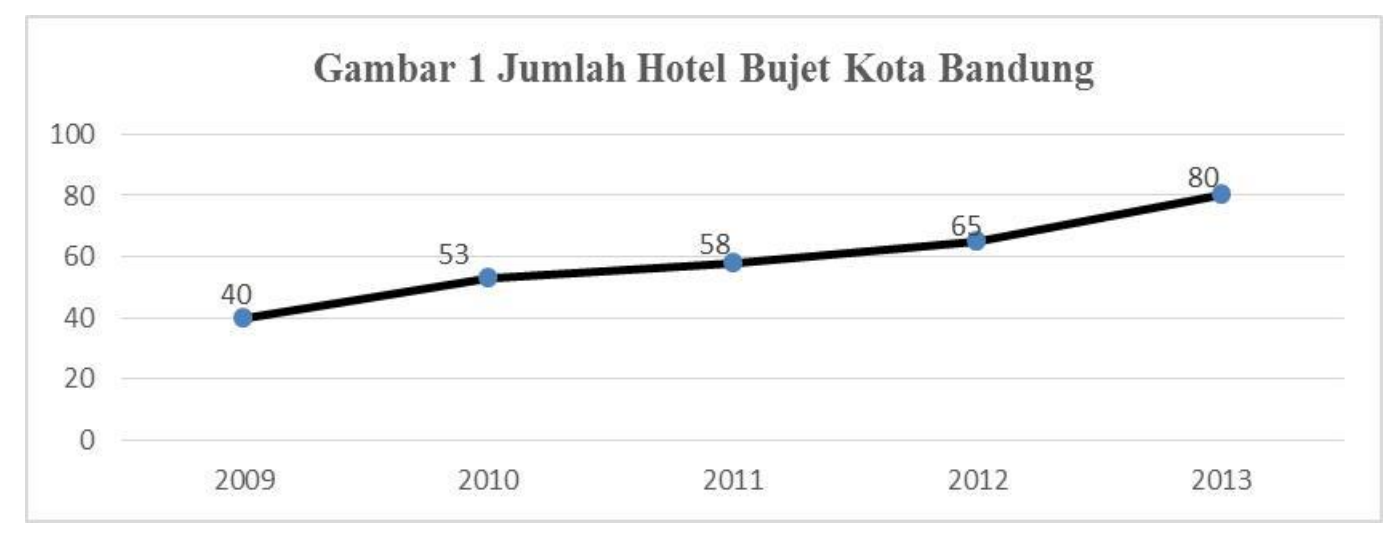

Sumber: BPS Kota Bandung, 2015

Penelitian Zhang (2013) menyatakan pertumbuhan sektor hotel bujet begitu cepat pada 10 tahun terakhir dengan berbagai merek hotel, jumlah unit kamar dan pengaruh sosial.

Demikian juga dengan jumlah kamar dan jumlah tempat tidur mengalami kenaikan. Jumlah kamar tumbuh sebesar $44,18 \%$ dan jumlah tempat tidur tumbuh sebesar 39,74\% pada periode yang sama diperlihatkan pada gambar 2 .

Kenyataan saat ini perkembangan jumlah hotel tidak selaras dengan tingkat hunian kamar di kota Bandung, terlihat dari data Perhimpunan Hotel dan Restoran Indonesia PHRI Kota Bandung. Bandung bulan Agustus 2016 dimana rata-rata tingkat hunian sebesar $90 \%$ pada Jum'at dan Sabtu, kemudian menurun di hari Minggu menjadi 50\% dan meningkat di hari Kamis sebesar 60\%.

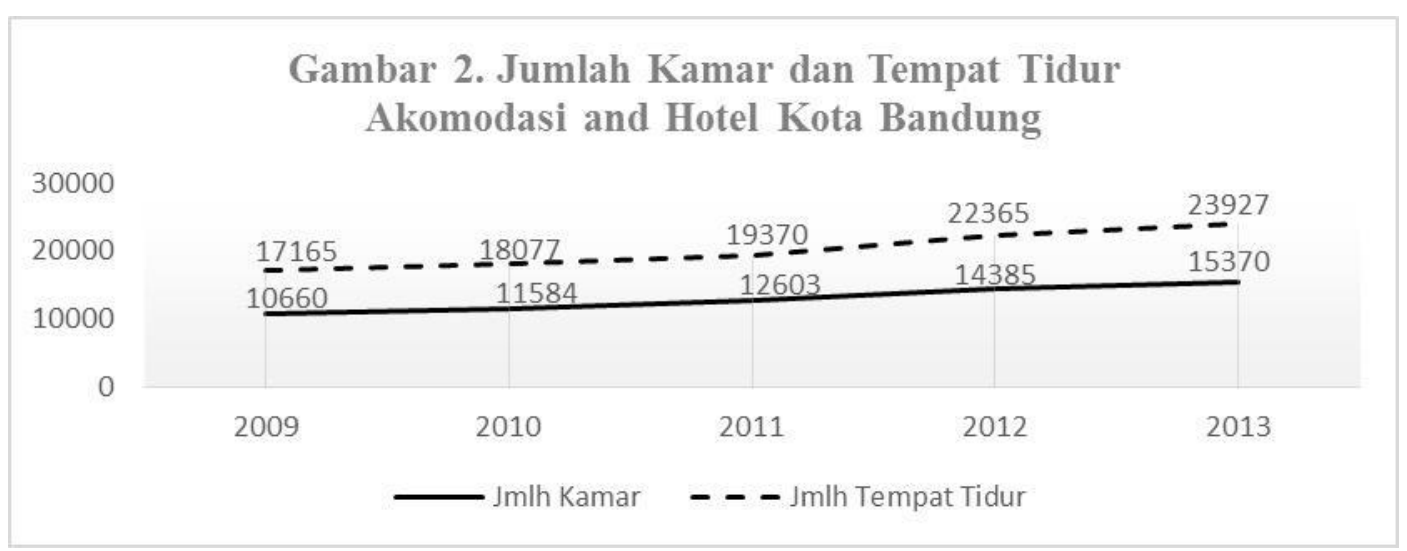

Sumber: BPS Kota Bandung, 2015

Terlepas dari tingkat hunian kamar, apakah kota Bandung mengalami over supply atau tidak, hotel yang menyediakan akomodasi harus memodifikasi dari manajemen hotel, layanan kualitas dan fasilitas untuk memberikan kenyamanan tamu. Tujuan dari modifikasi layanan kualitas adalah kepuasaan pelanggan, yang 
selanjutnya akan meningkatkan loyalitas pelanggan dan keuntungan perusahaan. Kepuasan pelanggan berkaitan dengan layanan kualitas yang diberikan hotel yang memenuhi keinginan dan kebutuhan pelanggan.

Pengguna hotel bujet akan menilai apa yang mereka dapat, mereka lihat dan rasakan dari pengalaman menginap di hotel. Pihak manajemen hotel haruslah tanggap dalam memenuhi harapan konsumen dan pihak manajemen hote tidak dapat bertindak atas kemauan sendiri dalam kebijakannya. Perwujudan kualitas layanan yang terbaik, komitmen dan memberikan rasa kepercayaan kepada konsumen, menjadikan hotel bujet sebagai pilihan pertama dan menjadikan konsumen lebih loyal.

Layanan hotel bujet melayani konsumen dan pelanggan tidak hanya dari pegawai hotel tetapi oleh semua lini yang ada di hotel bujet berupa keramahtamahan, cepat tanggap. Sehingga konsumen percaya terhadap komitmen layanan hotel yang akan membentuk loyalitas pelanggan dan akhirnya akan kembali menggunakan hotel bujet.

Penelitian Gilbert dan Lockwood (1990), hotel bujet di Amerika Serikat mulai pertama kalinya adalah Motel 6 harga kamar \$6/malam di California tahun 1963 dan hotel bujet mulai berkembang sejak 1970. Hotel bujet di dunia bertumbuh cepat dalam dekade terakhir. Pertumbuhan ini sejalan dengan perubahan perilaku konsumen, gaya hidup (life style) dan nilai menurut Fiorentino (1995), pertumbuhan jumlah wisatawan domestik, perkembangan ekonomi dan industri hotel (Ruetz dan Marvel, 2011). Investor hotel merubah strategi dengan membangun hotel bujet karena pasar lebih besar, keuntungan lebih tinggi dan market share lebih tinggi. Pengusaha harus menarik konsumen dengan paket layanan yang menawarkan harga kamar dan layanan yang menarik agar konsumen lebih lama tinggal dan tingkat utilitas kamar lebih tinggi.

Berdasarkan uraian dan fenomena di atas, peneliti tertarik untuk meneliti lebih lanjut hotel bujet di Bandung dengan tujuan menganalisa pengaruh kualitas layanan, tanggapan nilai dan harapan pelanggan terhadap kepuasan dan loyalitas pelanggan hotel bujet di Bandung. Peneliti mendapatkan data primer dari responden beberapa hotel bujet di Bandung, dan data diolah dengan Multiple Regression Analysis (MRA) software SPSS (Statistical Package for Social Science).

\section{TINJAUAN PUSTAKA}

\section{Kualitas Layanan}

Salah satu pendekatan kualitas layanan yang digunakan dalam penelitian ini adalah model SERVQUAL (Service Quality) yang dikembangkan oleh Parasuraman, Zeithmal dan Berry (1988): “a customer's judgment of the overall excellence or superiority of a service". Service quality dapat didefinisikan sebagai seberapa jauh perbedaan antara kenyataan dan harapan pelanggan atas pelayanan yang mereka terima atau peroleh. Harapan para pelanggan pada dasarnya sama dengan layanan seperti apakah seharusnya diberikan oleh perusahaan kepada pelanggan. 

bentuk:

Kualitas layanan yang diterima oleh pengguna ataupun pelanggan dalam

1. Tangibles, atau bukti fisik yaitu kemampuan suatu perusahaan dalam menunjukkan eksistensinya pada pihak eksternal. Penampilan dan kemampuan sarana dan prasarana fisik perusahaan dan keadaan lingkungan sekitarnya adalah bukti nyata dari pelayanan yang diberikan oleh pemberi jasa. ini meliputi fasilitas fisik (gedung, gudang, dan lainnya), teknologi (peralatan dan perlengkapan yang dipergunakan), serta penampilan pegawainya.

2. Reliability, atau kehandalan yaitu kemampuan perusahaan untuk memberikan pelayanan sesuai yang dijanjikan secara akurat dan terpercaya. Harus sesuai dengan harapan pelanggan berarti kinerja yang tepat waktu, pelayanan tanpa kesalahan, sikap simpatik dan dengan akurasi tinggi.

3. Responsiveness, atau ketanggapan yaitu suatu kemauan untuk membantu dan memberikan pelayanan yang cepat (responsive) dan tepat kepada pelanggan, dengan penyampaian informasi yang jelas. Membiarkan konsumen menunggu tanpa alasan yang jelas menyebabkan persepsi yang negatif dalam kualitas pelayanan.

4. Assurance, atau jaminan dan kepastian yaitu pengetahuan, kesopan santunan, dan kemampuan para pegawai perusahaan untuk menumbuhkan rasa percaya pelanggan kepada perusahaan. Terdiri dari komponen: komunikasi (Communication), kredibilitas (Credibility), keamanan (Security), kompetensi (Competence), dan sopan santun (Courtesy).

5. Empathy, yaitu memberikan perhatian yang tulus dan bersifat individual atau pribadi yang diberikan kepada pelanggan dengan berupaya memahami keinginan konsumen. Suatu perusahaan diharapkan memiliki suatu pengertian dan pengetahuan tentang pelanggan, memahami kebutuhan pelanggan secara spesifik, serta memiliki waktu pengoperasian yang nyaman bagi pelanggan.

Kualitas layanan sebagai faktor prediksi untuk kepuasan pelanggan mempunyai keterbatasan, karena kualitas layanan normalnya diukur dengan evaluasi kognitif pada atribut produk dan jasa hotel, Hemmington, N., (2007), menyatakan bahwa kepuasan pelanggan tergantung pada pengalaman total selama menginap di hotel meliputi produk fisik, performa staf, lingkungan dan atmosfir hotel dan evaluasi kognitif dan emosional.

\section{Tanggapan Nilai}

Beberapa penelitian tentang tanggapan nilai antara lain, Heskett and Sasser, (2010) membuktikan hubungan peran antara perilaku layanan dan tanggapan kualitas dan nilai jasa dalam manajemen / pemasaran.

Tanggapan nilai sebagai penilaian psikologis atas produk atau jasa dengan harapan yang diinginkan dari produk atau jasa yang mengindikasikan manfaat produk atau jasa perusahaan (Birgelen, Wetzels, and de Ruyter, 1997). 
Tangggapan nilai sebagai faktor utama yang mempengaruhi kepuasan pelanggan (Bolton and Drew, 1991). Hubungan positif antara tanggapan nilai dan kepuasan pelanggan dikemukakan oleh Patterson and Spreng,( 1997). Tanggapan nilai atau perceived value adalah opini atau tanggapan konsumen atau pelanggan pada nilai produk yang digunakannya. Konsumen membandingkan antara manfaat dan biaya dari produk atau jasa.

Bagi perusahaan, dimensi tanggapan nilai berarti biaya yang dikeluarkan oleh perusahaan dengan biaya relatif lebih rendah dibandingkan dengan pesaing, untuk memuaskan pelanggan lebih tinggi.

Peter Doyle (2009), mengemukakan 4 (empat) konsep nilai :

1. Nilai fungsi (functional value) - apa yang ditawarkan dari suatu produk atau jasa. Masalah apa yang dipecahkan dari penggunaan produk atau jasa

2. Nilai finansial (financial value) - dimana kegunaan produk dikaitkan dengan jumlah uang yang dikeluarkan, ada trade-offs antara biaya atas barang yang digunakan atau dibutuhkan dengan nilai guna barang atau jasa.

3. Nilai sosial (social value) - kepemilikan suatu produk memungkinkan pelanggan dapat berhubungan dengan pelanggan lain

4. Nilai psikologis (psychological value) - dimana pelanggan dapat mengekspresikan diri atau merasa lebih baik dari penggunaan produk. Seperti bangga, nyaman, bahagia.

\section{Harapan Pelanggan}

Harapan pelanggan didefinisikan sebagai keyakinan dan kepekaan bahwa setiap pelanggan memiliki harapan tentang produk atau layanan dari apa yang mereka butuhkan dan dari apa yang mereka andaikan lakukan.

Ketika konsumen mengkonsumsi produk atau jasa dan dirasakan sebagai pengalaman luar biasa maka kemungkinan besar konsumen akan kembali lagi menggunakannya. Evaluasi perlu dilakukan oleh produsen pada kepuasan pelangan agar terjadi loyalitas pelanggan dan pembelian kembali produk atau jasanya.

Knutson (1988) mendefinisikan harapan pelanggan sebagai gambaran utama tentang produk atau layanan yang disediakan sama dengan produk atau layanan yang diinginkan. Bentuk harapan pelanggan menurut Knutson (1988) adalah merefleksikan evaluasi penggunaan produk pada masa lalu dan sekarang :

1. Performa eksplisit (explicit performance) sebagai performa standar dari produk atau jasa yang jelas diberikan atau digambarkan oleh perusahaan yang akan diterima oleh konsumen

2. Performa implisit (implisit expectation) performa yang dibuat oleh bisnis umumnya atau perusahaan, industri lainnya yang tidak dinyatakan secara jelas.

3. Static performance expectations, performa yang ditampilkan oleh suatu produk atau jasa sama saja tidak ada perbedaan dari sebelumnya

4. Dynamic perfomance expectation, , performa yang ditampilkan oleh suatu produk atau jasa ada perbedaan dari sebelumnya 
5. Technology Expectation, teknologi dari produk atau jasa yang ditawarkan melebihi dari yang diharapkan konsumen. Kelengkapan fitur produk pada suatu produk atau jasa ditawarkan lebih dari apa yang dibayangkan oleh konsumen.

Beberapa studi tentang pentingnya harapan pelanggan pada kepuasan harapan, bagaimana mengelola harapan pelanggan yag sesuai dengan harapan pelanggan (Boulding, Kalra, Staelin, and Zeithaml, 1993); (Parasuraman, Zeithaml, and Berry, 1985). Harapan pelanggan adalah kunci daripada kepuasan pelanggan, kesukaan dan loyalitas sebagaimana dinyatakan oleh Kotler, P. Bowen, J.T., and Makens. J, (2014).

Perusahaan harus mengidentifikasi kebutuhan dan harapan dari pelangggan untuk mencapai harapan pelanggan yang tertinggi (Parasuraman, Berry, and Zeithaml, 1991). Mengelola dan memenuhi harapan pelanggan adalah alat yang baik untuk menyediakan kepuasan pelanggan (Pitt and Jeantrout, 1994).

\section{Kepuasan Pelanggan}

Kepuasan pelanggan telah menjadi konsep utama dalam literatur marketing dan sebagai tujuan penting dari kegiatan usaha. Saat ini, perusahaan menghadapi persaingan ketat, dimana ada pergeseran dari filosofi produk dan penjualan menjadi filosofi marketing. Secara kesseluruhan kepuasan pelanggan adalah memberikan lebih banyak profit untuk perusahaan dan meningkatkan makret share.

Kotler dan Keller (2012) mendefinisikan "satisfication is person's feeling of pleasure or disappointment which resulted from comparing a product's perceived performance or outcome against his/ her expectations"

Dimensi kepuasan pelanggan Kotler dan Keller (2012), sebagai berikut :

1. Competitive Pricing, pelanggan puas atas harga perusahaan yang mampu bersaing dengan produk atau jasa sejenis pesaing

2. Service Quality, pelanggan puas akan kualitas jasa atau produk yang ditawarkan sesuai dengan promosi jasa atau produk

3. Quick Service, kecepatan layanan dimana pelanggan tidak terlalu lama menunggu

4. Good Value, dimana produk atau jasa memberikan nilai yang baik

5. Billing Clarify, Accuracy Billing and Billing Timeliness, pelanggan puas atas kejelasan tagihan dan kecepatan permintaan tagihan

6. Helpful and Friendly Employees, kepuasan diukur dari layanan pegawai yang sangat membantu dan ramah dalam memenuhi kebutuhan pelanggan

Penelitian Hokanson (1995), beberapa faktor yang termasuk mempengaruhi kepuasan pelanggan adalah pegawai yang ramah, pegawai yang bersahabat, pengetahuan pegawai, pengawai yang membantu, akurasi tagihan, kecepatan tagihan, harga kompetitif, kualitas layanan, nilai yang baik, kejelasan tagihan dan kecepatan layanan. 


\section{Loyalitas Pelanggan}

Gramer dan Brown dalam Utomo (2006) memberikan definisi mengenai loyalitas jasa sebagai derajat sejauh mana konsumen menunjukkan perilaku pembelian berulang dari suatu penyedia jasa, memiliki suatu desposisi atau kecenderungan sikap positif terhadap penyedia jasa, dan hanya mempertimbangkan untuk meggunakan penyedia jasa ini pada saat muncul kebutuhan untuk memakai jasa tersebut. Konsumen yang loyal tidak hanya seorang pembeli yang melaukan pembelian berulang tetapi juga mempertahankan sikap positif terhadap penyedia jasa.

Menurut Bramson (2005:2) loyalitas konsumen merupakan suatu konsep yang mencakup lima faktor yaitu pengalaman konsumen dengan kepuasan utuh ketika melakukan transaksi dengan anda, kesediaan untuk mengembangkan hubungan dengan anda dan dengan perusahaan anda, kesediaan untuk menjadi pembeli setia, kesediaan untuk merekomendasikan anda kepada orang lain, dan penolakan untuk berpindah pada pesaing.

Kepuasan pelanggan memberikan pengaruh positif pada keuntungan perusahaan. Semakin banyak pelanggan puas dengan produk dan jasa yang ditawarkan, lebih banyak peluang untuk lebih berhasilnya bisnis dengan adanya pembelian lang, loyalitas merk, marketing yang positif dari pemasaran dari mulut ke mulut. Kepuasan pelangan mengarahkan pada pembelian ulang, loyalitas pelanggan dan retensi pelanggan (Zairi, 2000)

\section{METODE PENELITIAN}

\section{Jenis Penelitian}

Jenis penelitian ini adalah kausal konklusif yaitu penelitian yang bertujuan untuk memperoleh suatu kesimpulan dari data-data yang telah diperoleh dan diolah yang menjelaskan hubungan sebab akibat antara variabel-variabel yang dibahas dalam penelitian ini.

\section{Populasi dan Sampel}

Populasi dan sampel penelitian ini adalah pengguna hotel bujet di Bandung. Metode random sampling digunakan untuk mendapatkan data primer melalui kuesioner untuk dijawab oleh responden. Kuesioner didistribusikan kepada 200 responden di 10 hotel bujet di Bandung antara 8 Oktober - 10 November 2016.

\section{Variabel Penelitian \\ Jenis Variabel}

1. Variabel Independent atau variabel bebas dalam penelitian ini adalah kualitas layanan (X1), tanggapan nilai (X2) dan harapan pelanggan (X3).

2. Variabel Intervening(antar) dalam penelitian ini adalah kepuasan pelanggan (Y1),

3. Variabel Dependent atau variabel terikat dalam penelitian ini dan loyalitas pelanggan (Y2) 


\section{Operasional Variabel}

\section{Tabel 1. Operasionalisasi Variabel}

\begin{tabular}{|c|c|c|c|c|}
\hline Variabel & Dimensi & Indikator / Item & Kode & Skala \\
\hline \multirow[t]{5}{*}{$\begin{array}{c}\text { Kualitas Layanan } \\
\text { X1 } \\
\text { Parasuraman, } \\
\text { Zeithmal dan Berry } \\
\text { (1988) }\end{array}$} & $\begin{array}{l}\text { Tangible (Bukti } \\
\text { Fisik) }\end{array}$ & $\begin{array}{l}\text { 1. Kebersihan kamar hotel } \\
\text { 2. Kebersihan kamar } \\
\text { mandi } \\
\text { 3. Kualitas makan pagi } \\
\text { 4. Kecepatan internet } \\
\text { tinggi dan memadai }\end{array}$ & $\begin{array}{l}\text { KL1 } \\
\text { KL2 } \\
\text { KL3 } \\
\text { KL4 }\end{array}$ & \multirow{4}{*}{ Ordinal } \\
\hline & $\begin{array}{l}\text { Reability } \\
\text { (Kehandalan) }\end{array}$ & $\begin{array}{l}\text { 1. Pelayanan sesuai yang } \\
\text { dijanjikan } \\
\text { 2. Pelayanan pegawai } \\
\text { tepat waktu, } \\
\text { 3. Pelayanan tanpa } \\
\text { kesalahan dengan } \\
\text { akurasi tinggi. }\end{array}$ & $\begin{array}{l}\text { KL5 } \\
\text { KL6 } \\
\text { KL7 }\end{array}$ & \\
\hline & $\begin{array}{l}\text { Responsiveness } \\
\text { (Daya Tanggap) }\end{array}$ & $\begin{array}{l}\text { 1. Kesediaan pegawai } \\
\text { memberikan layanan } \\
\text { cepat } \\
\text { 2. Kesediaan menanggapi } \\
\text { keluhan atau kesulitan } \\
\text { pelanggan dengan cepat } \\
\text { 3. Pengawai memberikan } \\
\text { informasi yang cepat }\end{array}$ & $\begin{array}{l}\text { KL8 } \\
\text { KL9 } \\
\text { KL10 }\end{array}$ & \\
\hline & $\begin{array}{l}\text { Assurance } \\
\text { (Jaminan) }\end{array}$ & $\begin{array}{l}\text { 1. Kompetensi pegawai } \\
\text { dalam layanan } \\
\text { 2. Keramahtamahan } \\
\text { pegawai dalam } \\
\text { melayani } \\
\text { 3. Reputasi hotel bujet }\end{array}$ & $\begin{array}{l}\text { KL11 } \\
\text { KL12 } \\
\text { KL13 }\end{array}$ & \\
\hline & Emphaty (Empati) & $\begin{array}{l}\text { 1. Perhatian yang tulus } \\
\text { dari pegawai } \\
\text { 2. Pegawai Hotel } \\
\text { memperhatikan dengan } \\
\text { sungguh-sungguh } \\
\text { kebutuhan pelanggan } \\
\text { 3. Pegawai hotel }\end{array}$ & $\begin{array}{l}\text { KL14 } \\
\text { KL15 }\end{array}$ & \\
\hline \multirow[t]{3}{*}{$\begin{array}{c}\text { Tanggapan Nilai } \\
\text { X2 } \\
\text { Peter Doyle (2009) }\end{array}$} & Nilai Fungsi & $\begin{array}{l}\text { 1. Hotel sesuai dengan } \\
\text { kebutuhan akomodasi } \\
\text { 2. Kenyamanan } \\
\text { akomodasi } \\
\text { 3. Kamar hotel sesuai } \\
\text { dengan keinginan }\end{array}$ & $\begin{array}{l}\text { TN1 } \\
\text { TN2 } \\
\text { TN3 }\end{array}$ & \multirow{3}{*}{ Ordinal } \\
\hline & Nilai Finansial & $\begin{array}{l}\text { 1. Harga bersaing } \\
\text { 2. Harga sesuai anggaran } \\
\text { 3. Harga sesuai dengan } \\
\text { penawaran }\end{array}$ & $\begin{array}{l}\text { TN4 } \\
\text { TN5 } \\
\text { TN6 }\end{array}$ & \\
\hline & Nilai Sosial & $\begin{array}{l}\text { 1. Hubungan sosialisasi } \\
\text { dengan pelanggan lain } \\
\text { 2. Lokasi hotel dekat kota }\end{array}$ & $\begin{array}{l}\text { TN7 } \\
\text { TN8 }\end{array}$ & \\
\hline
\end{tabular}




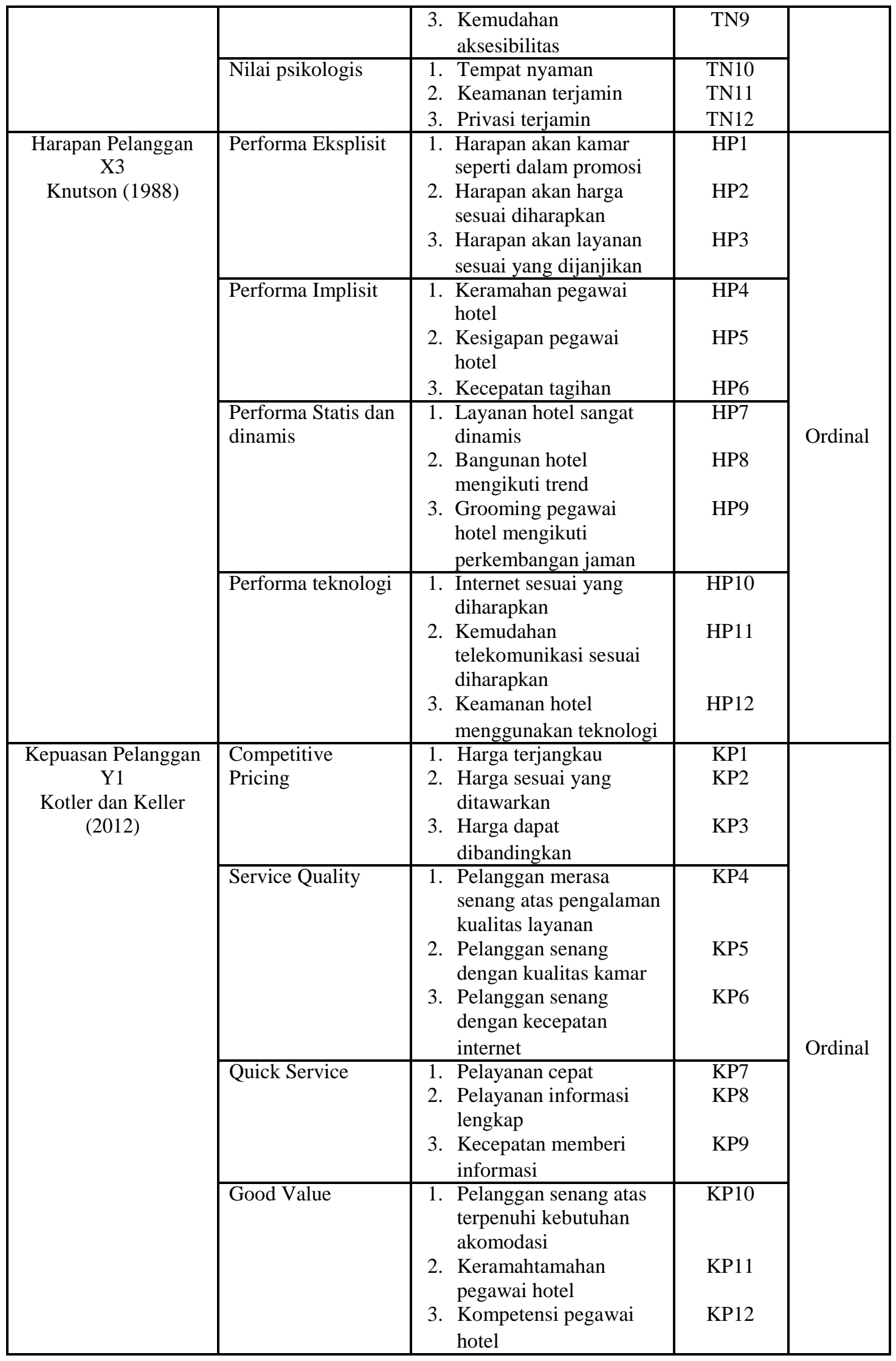




\begin{tabular}{|c|c|c|c|c|}
\hline \multirow[t]{4}{*}{$\begin{array}{c}\text { Loyalitas Pelanggan } \\
\text { Y2 } \\
\text { Kumar, V., Shah , D } \\
\text { (2004). }\end{array}$} & Pertimbangan & $\begin{array}{l}\text { 1. Mempertimbangkan } \\
\text { kualitas layanan hotel } \\
\text { bujet sebagai pilihan } \\
\text { pertama } \\
\text { 2. Mempertibangkan } \\
\text { manfaat dibandingkan } \\
\text { harga }\end{array}$ & LP1 & \multirow[t]{4}{*}{ Ordinal } \\
\hline & Rekomendasi & $\begin{array}{l}\text { 1. Pelanggan merekomen- } \\
\text { dasikan hotel bujet } \\
\text { kepada teman, keluarga } \\
\text { dan koleganya } \\
\text { 2. Memberi nilai yang } \\
\text { baik kinerja pegawai }\end{array}$ & LP4 & \\
\hline & $\begin{array}{l}\text { Berbicara hal } \\
\text { positif }\end{array}$ & $\begin{array}{l}\text { 1. Pelanggan } \\
\text { membicarakan hal-hal } \\
\text { positif kepada teman, } \\
\text { keluarga dan koleganya } \\
\text { 2. Menceritakan } \\
\text { pengalaman menginap }\end{array}$ & LP6 & \\
\hline & $\begin{array}{l}\text { Niat untuk } \\
\text { melakukan } \\
\text { transaksi }\end{array}$ & $\begin{array}{l}\text { 1. Niat untuk terus } \\
\text { melakukan booking } \\
\text { dengan hotel bujet } \\
\text { 2. Menjadi member hotel } \\
\text { bujet }\end{array}$ & LP7 & \\
\hline
\end{tabular}

Sumber: Pengolahan Data Penelitian

\section{Analisis Data}

\section{Uji Deskriptif}

Data yag diolah adalah rerata item dari masing-masing variabel yang diperoleh dari 200 responden. Pada penelitian ini tidak diukur hubungan ataupun pengaruh dari dimensi dan indikator. Uji deskriptif digunakan untuk menganalisis data dengan cara mendeskripsikan atau menggambarkan data yang terkumpul sebagaimana aanya tanpa bermaksud membuat kesimpulan yang berlaku untuk umum atau generalisasi.

\section{Analisis Jalur}

Penelitian ini menggunakan analisis jalur untuk menguji kelinearan model, namun juga hubungan serta besar pengaruhnya diantara variabel kausalnya. Variabel kausal yang ada yaitu kualitas layanan, tanggapan nilai, harapan pelanggan, kepuasan pelnggan dan loyalitas pelanggan.

Analisis jalur (path analysis) yang merupakan perluasan dari analisis regresi berganda untuk menaksir hubungan kausalitas antara variabel yang telah ditetapkan sebelumnya berdasarkan teori (Trihendradi. C, 2013)

Gambar 3 memperlihatkan analisis jalur penelitian ini. Terdapat dua jalur rantai kausal, yaitu jalur-jalur variabel yang membentuk kepuasan pelanggan dan jalur-jalur variabel yang membentuk loyalitas pelanggan. Rantai kausal yang membentuk kepuasan pelanggan dipengaruhi oleh jalur variabel kualitas layanan, tanggapan nilai dan harapan pelanggan. Sedangkan jalur-jalur variabel yang membentuk loyalitas pelanggan dipengaruhi oleh jalur variabel kualitas layanan, harapan pelanggan dan kepuasan pelanggan. 


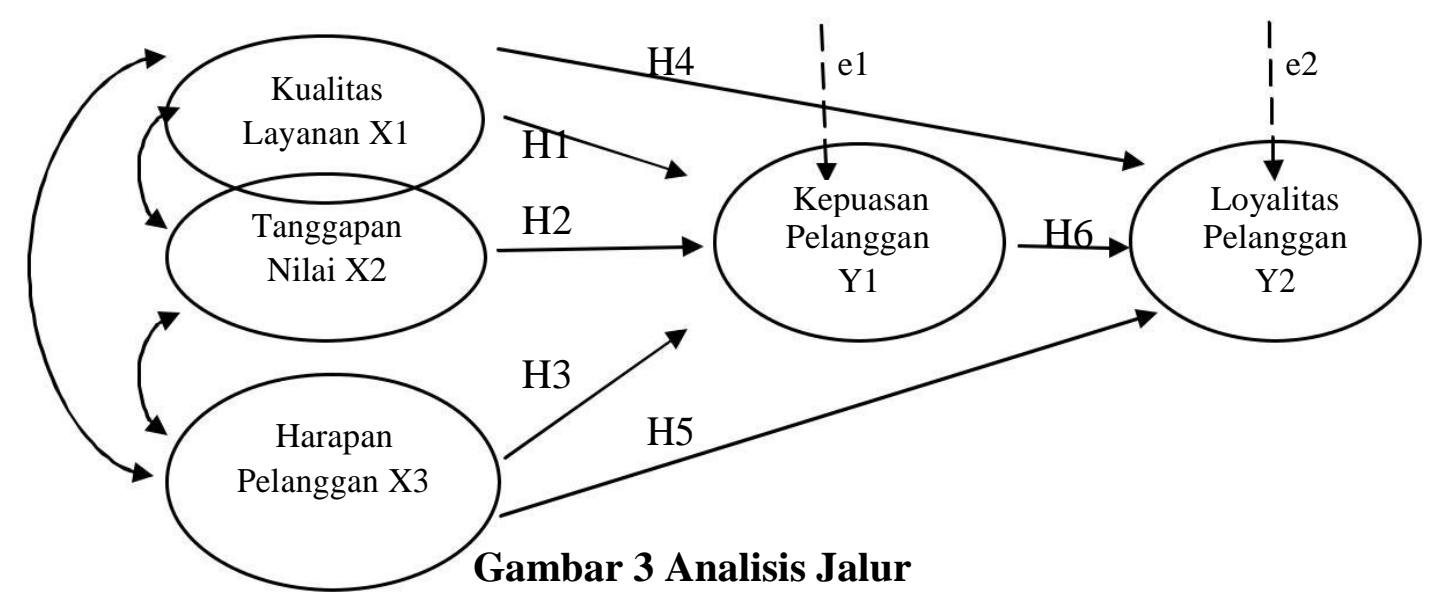

Rantai kausal yang terbentuk yaitu:

a. Y1 (kepuasan pelanggan) dengan jalur-jalur variabel X1 (kualitas layanan), X2 (tanggapan nilai) dan X3 (harapan pelanggan), dengan persamaan jalur $\mathrm{Y} 1=\mathrm{PX} 1+\mathrm{PX} 2+\mathrm{PX} 3+\mathrm{e} 1$

b. Y2 (loyalitas pelanggan) dengan jalur-jalur variabel X1 (kualitas layanan), X3 (harapan pelanggan) dan $\mathrm{Y} 1$ (kepuasan pelanggan) dengan persamaan jalur $\mathrm{Y} 2=\mathrm{PX} 1+\mathrm{PX} 3+\mathrm{Y} 1+\mathrm{e} 1$

\section{Uji Hipotesis}

Uji hipotesis yang diajukan dalam penelitian ini, sebagai berikut :

H1: Kualitas layanan (X1) mempengaruhi langsung kepuasan pelanggan (Y1) hotel bujet di Bandung

$\mathrm{H} 2$ : Tanggapan nilai (X2) mempengaruhi langsung kepuasan pelanggan hotel bujet di Bandung

H3: Harapan pelanggan (X3) mempengaruhi langsung kepuasan pelanggan (Y1) hotel bujet di Bandung

H4: Kualitas layanan (X1) mempengaruhi langsung loyalitas pelanggan (Y2) hotel bujet di Bandung

H5: Harapan pelanggan (X3) mempengaruhi langsung loyalitas pelanggan (Y2) hotel bujet di Bandung

H6: Kepuasan pelanggan (Y1) mempengaruhi langsung loyalitas pelanggan (Y2) hotel bujet di Bandung

Nilai yang digunakan dalam analisis jalur adalah nilai standardized coefficient. Untuk mengetahui ada pengaruh maka dapat dirumuskan sebagai berikut:

Nilai sig < 0.01: H0 ditolak

Nilai sig > 0.01: Ha diterima 


\section{HASIL DAN PEMBAHASAN}

\section{Uji Reliabilitas Data}

Peneliti mengawali dengan studi awal yaitu pre-test dari quesioner melibatkan 30 orang untuk uji validitas dan reliabilitas quesioner dan kemudian diadakan revisi quesioner. Analisa reliabilitas menggunakan prosedur alpha Cronbach, diperlihatkan tabel 2.

Semua nilai variabel dengan nilai Cronbach's Alpha lebih besar daripada 0.60, mengindikasikan tingkat relibiltas semua variabel tinggi. Juga menunjukkan jawaban dari responden konsisten dan stabil.

Tabel 2. Reliability Analysis

\begin{tabular}{lcc}
\hline \multicolumn{1}{c}{ Name of Variable } & $\begin{array}{c}\text { Number of Items } \\
\text { included }\end{array}$ & Cronbach's Alpha \\
\hline Kepuasan Pelanggan & 12 & 0906 \\
Loyalitas Pelanggan & 8 & 0.863 \\
Kualitas Layanan & 16 & 0.906 \\
Tanggapan Nilai & 12 & 0.863 \\
Harapan Pelanggan & 12 & 0.896 \\
\hline Sumber: Olahan penelitian, 2016 & &
\end{tabular}

\section{Profil Responden}

Tabel 3 memperlihatkan profil responden, dimana responden terdiri dari $63,50 \%$ laki-laki dan $36,50 \%$ perempuan.

Tabel 3. Profil Responden

\begin{tabular}{llr}
\hline \multicolumn{1}{c}{ Variabel } & \multicolumn{1}{c}{ Kategori } & Persentase \\
\hline Jenis Kelamin & Laki-laki & 63.50 \\
\multirow{2}{*}{ Pekerjaan } & Perempuan & 36.50 \\
& Pegawai Negeri Sipil & 7.00 \\
& Pegawai Swasta & 57.00 \\
& Wirausaha / pengusaha/ & 36.00 \\
& Selfemployee & \\
Usia & $<25$ tahun & 6.00 \\
& 26 - 45 tahun & 64.00 \\
& $46-55$ tahun & 22.50 \\
Penghasilan / bulan & $>55$ tahun & 7.50 \\
& $<6$ Juta & 62.50 \\
& 6-12 Juta & 28.50 \\
& $>12$ juta & 9.00 \\
\hline
\end{tabular}

Sumber: olahan penelitian 2016

Pekerjaan responden terbanyak dari pegawai swasta sebesar 57\%, wirausaha $36 \%$ dan pegawai negeri $7 \%$. Usia responden adalah usia produktif, dimana umur 26 - 55 tahun sebesar $86,5 \%$ dan penghasilan perbulan kurang dari 6 Juta sebesar $62,5 \%$, antara $6-12$ juta sebesar $28,50 \%$. Responden pengguna 
hotel bujet di Bandung dalam usia produktif 26 - 55 tahun dan penghasilan menengah. Rerata responden pegawai swasta dan wirausaha total sebanyak $93 \%$ dan penghasilan di bawah 12 juta sebanyak $91 \%$ memilih hotel bujet kemungkinan karena sesuai dengan fungsi hotel sebagai hanya tempat akomodasi dan sesuai dengan daya beli dan penghasilan pengguna.

Untuk menginvestigasi jenis kelamin yang memberi perbedaan pada kepuasan pelanggan, digunakan t-test sebagaimana tabel 4

Tabel 4. Jenis Kelamin dan Kepuasan Pelanggan

\begin{tabular}{|c|c|c|c|c|c|c|c|}
\hline & \multirow[b]{2}{*}{$\begin{array}{c}\text { Jenis } \\
\text { Kelamin }\end{array}$} & \multirow[b]{2}{*}{$\mathbf{N}$} & \multirow[b]{2}{*}{ Mean } & \multirow[b]{2}{*}{$\begin{array}{l}\text { Standard } \\
\text { Deviation }\end{array}$} & \multirow{2}{*}{$\begin{array}{c}\text { Standard } \\
\text { Error } \\
\text { Mean }\end{array}$} & \multicolumn{2}{|c|}{ T-test for Equality of Means } \\
\hline & & & & & & t-value $\quad$ d.f. & Sig. (2-tailed) \\
\hline Kepuasan & Laki-laki & 127 & 29.44 & 4.50 & 0.22 & -0.853 & 0.289 \\
\hline Pelanggan & Perempuan & 73 & 28.50 & 4.15 & 0.30 & & \\
\hline
\end{tabular}

Sumber: Olahan penelitian, 2016

Hasil t-test menyatakan bahwa jenis kelamin tidak signifikan $0.289<0.01$ yang membedakan faktor-faktor yang diidentifikasikan sebagai kepuasan pelanggan.

\section{Analisa Korelasi}

Tabel5. Correlations, pada kolom kepuasan pelanggan (Y1) dan hubungannya dengan variabel kausal lainnya menunjukkan hubungan yang positif dan mempunyai hubungan signifikan dengan nilai Sig (2-tailed), semuanya lebih kecil daripada $\alpha(0.01)$.

Kolom loyalitas pelanggan juga memiliki hubungan positif dengan variabel kausal lainnya dan juga hubungan signifikan dimana nilai Sig (2-tailed), semuanya lebih kecil daripada $\alpha(0.01)$.

\section{Tabel 5. Correlations}

\begin{tabular}{|c|c|c|c|c|c|c|}
\hline & & $\begin{array}{r}\text { Kualitas_ } \\
\text { Layanan }\end{array}$ & $\begin{array}{c}\text { Tanggapan } \\
\text { Nilai }\end{array}$ & $\begin{array}{l}\text { Harapan_ } \\
\text { Pelanggan }\end{array}$ & $\begin{array}{c}\text { Kepuasan_ } \\
\text { Pelangan }\end{array}$ & $\begin{array}{l}\text { Loyalitas_ } \\
\text { Pelanggan }\end{array}$ \\
\hline \multirow{4}{*}{ Kualitas_Layanan } & Pearson Correlation & 1 & .599 & .356 & .539 & .647 \\
\hline & Sig. (2-tailed) & & .000 & .000 & .000 & .000 \\
\hline & $\mathrm{N}$ & 200 & 200 & 200 & 200 & 200 \\
\hline & Pearson Correlation & .599 & 1 & .632 & .754 & .739 \\
\hline \multirow[t]{3}{*}{ Tanggapan_Nilai } & Sig. (2-tailed) & .000 & & .000 & .000 & .000 \\
\hline & & 200 & 200 & 200 & 200 & 200 \\
\hline & Pearson Correlation & $.356^{\cdots \cdots}$ & $.632^{\cdots+1}$ & 1 & $.647^{\cdots+1}$ & $.689^{\cdots+1}$ \\
\hline \multirow[t]{3}{*}{ Harapan_Pelanggan } & Sig. (2-tailed) & .000 & .000 & & .000 & .000 \\
\hline & $\mathrm{N}$ & 200 & 200 & 200 & 200 & 200 \\
\hline & Pearson Correlation & .539 & .754 & .647 & 1 & .849 \\
\hline \multirow[t]{3}{*}{ Kepuasan_Pelangan } & Sig. (2-tailed) & .000 & .000 & .000 & & .000 \\
\hline & & 200 & 200 & 200 & 200 & 200 \\
\hline & Pearson Correlation & $.647^{* * *}$ & $.739^{* * *}$ & $.689^{* * *}$ & $.849^{* *}$ & 1 \\
\hline \multirow[t]{2}{*}{ Loyalitas_Pelanggan } & Sig. (2-tailed) & .000 & .000 & .000 & .000 & \\
\hline & $\mathrm{N}$ & 200 & 200 & 200 & 200 & 200 \\
\hline
\end{tabular}

**. Correlation is significant at the 0.01 level (2-tailed).

Sumber: Olahan penelitian, 2016 
Beberapa penelitian, Parasuraman (1988) mengidikasikan tanggapan nilai mempunyai pengaruh positif pada kepuasan pelanggan. Penelitian Pitt and Jeantrout, (1994), koefisien harapan pelanggan mengindikasikan jika harapan pelanggan dan kepuasan pelanggan mempunyai hubungan yang positif.

\section{Analisa Jalur}

\section{Pengaruh Kualitas Layanan (X1), Tanggapan Nilai (X2) dan Harapan Pelanggan (X3) terhadap Kepuasan Pelanggan (Y1)}

Untuk mendapatkan hasil pengaruh kualitas layanan (X1), tanggapan nilai (X2) dan harapan pelanggan (X3) terhadap kepuasan pelanggan (Y1) menggunakan analisa regresi pada model rantai kausal yang pertama.

Persamaan jalur: Y1 = PX1 (kualitas layanan) + PX2 (tanggapan nilai) + PX3 (harapan pelanggan) $+\mathrm{e} 1$.

Tabel 6, model summary menunjukkan nilai $\mathrm{R}$ kuadrat atau koefisien determinasi sebesar 0.63 atau $63 \%$.

\section{Tabel 6. Model Summary}

\begin{tabular}{|l|r|r|r|r|r|}
\hline $\begin{array}{l}\text { Mode } \\
1\end{array}$ & R & R Square & $\begin{array}{c}\text { Adjusted R } \\
\text { Square }\end{array}$ & $\begin{array}{l}\text { Std. Error of } \\
\text { the Estimate }\end{array}$ & $\begin{array}{l}\text { Durbin- } \\
\text { Watson }\end{array}$ \\
\hline 1 & $.794^{\mathrm{a}}$ & .630 & .624 & .19103 & 1.576 \\
\hline
\end{tabular}

a. Predictors: (Constant), Harapan_Pelanggan, Kualitas_Layanan,

Tanggapan_Nilai

b. Dependent Variable: Kepuasan_Pelanggan

Sumber: Olahan penelitian, 2016

Pengaruh besarnya variabel kualitas layanan, tanggapan nilai, harapan pelanggan terhadap kepuasan pelanggan adalah $63 \%$ atau variabel lain mempengaruhi sebesar $37 \%$

Untuk menguji model rantai kausal pertama linear ditunjukkan tabel 7 ANOVA dengan hipotesis:

$$
\begin{aligned}
& \text { H0 = model rantai kausal tidak linear } \\
& \text { H1 = Model rantai kausal linear } \\
& \text { Sig }(0.000)<\alpha(0.01) \text { maka Ho ditolak, jadi model kausal } \\
& \text { tersebut linear }
\end{aligned}
$$

Tabel 7. ANOVA ${ }^{\mathrm{a}}$

\begin{tabular}{|rl|r|r|r|r|r|}
\hline Model & & Sum of Squares & Df & Mean Square & F & Sig. \\
\hline \multirow{3}{*}{1} & Regression & 12.180 & 3 & 4.060 & 111.261 & $.000^{\mathrm{b}}$ \\
& Residual & 7.152 & 196 & .036 & & \\
& Total & 19.332 & 199 & & & \\
\hline
\end{tabular}

a. Dependent Variable: Kepuasan_Pelanggan

b. Predictors: (Constant), Harapan_Pelanggan, Kualitas_Layanan, Tanggapan_Nilai Sumber: Pengolahan Data Penelitian 
Sumber: Olahan penelitian, 2016

Dari tabel $7 \mathrm{di}$ atas, variabel kualitas layanan, tanggapan nilai dan harapan pelanggan secara simultan memberikan pengaruh yang signifikan terhadap kepuasan pelanggan. Untuk melihat besarnya pengaruh masing-masing variabel kausal terhadap Y1 (kepuasan pelanggan) menggunakan tabel 8 coefficients.

Tabel 8. Coefficients ${ }^{\mathrm{a}}$

\begin{tabular}{|c|c|c|c|c|c|c|}
\hline \multirow{2}{*}{\multicolumn{2}{|c|}{ Model }} & \multicolumn{2}{|c|}{$\begin{array}{l}\text { Unstandardized } \\
\text { Coefficients }\end{array}$} & \multirow{2}{*}{$\begin{array}{l}\text { Standardized } \\
\text { Coefficients }\end{array}$} & \multirow[t]{2}{*}{$\mathrm{T}$} & \multirow[t]{2}{*}{ Sig. } \\
\hline & & $\mathrm{B}$ & $\begin{array}{l}\text { Std. } \\
\text { Error }\end{array}$ & & & \\
\hline \multirow{4}{*}{1} & (Constant) & .277 & .205 & & 1.350 & .179 \\
\hline & Kualitas_Layanan & 167 & .062 & .146 & 2.694 & .008 \\
\hline & Tanggapan_Nilai & .476 & .065 & .483 & 7.378 & .000 \\
\hline & Harapan_Pelanggan & .286 & .056 & .289 & 5.155 & .000 \\
\hline
\end{tabular}

a. Dependent Variable: Kepuasan_Pelanggan

Sumber: Olahan penelitian, 2016

Dari ketiga variabel yang mempengaruhi kepuasan pelanggan standardized Coefficients nilai tertinggi adalah variabel kausal tanggapan nilai $(\beta=0,483)$ diikuti harapan pelanggan $(\beta=0.289)$ dan paling rendah kualitas layanan $(\beta$ $=0.146$ ).

\section{Pengaruh Kualitas Layanan (X2), Harapan Pelanggan (X3) dan Kepuasan Pelanggan (Y1) terhadap Loyalitas Pelanggan (Y2)}

Untuk mendapatkan hasil pengaruh kualitas layanan (X2), harapan pelanggan (X3) dan kepuasan pelanggan (Y1) terhadap loyalitas pelanggan (Y2) menggunakan analisa regresi pada model rantai kausal kedua.

Persamaan jalur : $\mathrm{Y}_{2}=\mathrm{PX}_{1}($ kualitas layanan $)+\mathrm{PX}_{3}($ harapan pelanggan $)+\mathrm{Y}_{1}$

(kepuasan pelanggan) $+\mathrm{e} 2$

Tabel 9 Model Summary

\begin{tabular}{|c|r|r|r|r|}
\hline $\begin{array}{c}\text { Mode } \\
\mathbf{l}\end{array}$ & $\mathbf{R}$ & $\begin{array}{c}\text { R } \\
\text { Square }\end{array}$ & $\begin{array}{c}\text { Adjusted R } \\
\text { Square }\end{array}$ & $\begin{array}{c}\text { Std. Error of } \\
\text { the Estimate }\end{array}$ \\
\hline 1 & $.897^{\mathrm{a}}$ & .804 & .801 & .11504 \\
\hline
\end{tabular}

Predictors: (Constant), Kepuasan_Pelanggan, Kualitas_Layanan,

Harapan_Pelanggan

Sumber : Olahan penelitian, 2016

Pada tabel 9 model summary, nilai $\mathrm{R}$ square atau koefisien determinasi adalah 0.804 atau $80,40 \%$. Nilai tersebut menunjukkan besarnya pengaruh variabel kualitas layanan, harapan pelanggan dan kepuasan pelanggan terhadap variabel loyalitas pelanggan adalah $80,40 \%$. Atau pengaruh variabel lainnya (e2) sebesar $19,60 \%$ atau 0.196 . 


\section{ANOVA}

Untuk menguji model rantai kausal kedua linear ditunjukkan tabel 10

\section{Tabel 10 ANOVA ${ }^{a}$}

\begin{tabular}{|rl|r|r|r|r|r|}
\hline Model & \multicolumn{1}{|c|}{$\begin{array}{c}\text { Sum of } \\
\text { Squares }\end{array}$} & Df & Mean Square & F & Sig. \\
\hline \multirow{4}{*}{1} & Regression & 10.639 & 3 & 3.546 & 267.966 & $.000^{\circ}$ \\
& Residual & 2.594 & 196 & .013 & & \\
& Total & 13.23 & 199 & & & \\
\hline
\end{tabular}

Dependent Variable: Loyalitas_Pelanggan

Predictors: (Constant), Kepuasan_Pelanggan, Kualitas_Layanan, Harapan_Pelanggan

Sumber : Olahan peneliti, 2016

Hipotesis:

Ho $=$ model rantai kausal tidak linear

H1 = Model rantai kausal linear

Dari tabel didapat Sig $(0.000)<\alpha$ maka Ho ditolak, jadi model kausal tersebut linear

Untuk melihat besarnya pengaruh masing-masing variabel kausal terhadap Y2 (loyalitas pelanggan) menggunakan tabel 11 coefficients.

Tabel 11 Coefficients ${ }^{\mathrm{a}}$

\begin{tabular}{|c|c|c|c|c|c|c|}
\hline \multirow{2}{*}{\multicolumn{2}{|c|}{ Model }} & \multicolumn{2}{|c|}{$\begin{array}{c}\text { Unstandardized } \\
\text { Coefficients }\end{array}$} & \multirow{2}{*}{$\begin{array}{c}\begin{array}{c}\text { Standardized } \\
\text { Coefficients }\end{array} \\
\text { Beta }\end{array}$} & \multirow[b]{2}{*}{$\mathbf{t}$} & \multirow{2}{*}{ Sig. } \\
\hline & & B & $\begin{array}{c}\text { Std. } \\
\text { Error }\end{array}$ & & & \\
\hline \multirow{4}{*}{1} & (Constant) & .550 & .211 & & 4.432 & .000 \\
\hline & Kualitas_Layanan & .251 & .035 & .265 & 7.069 & .000 \\
\hline & Harapan_Pelanggan & .195 & .034 & .238 & 5.742 & .000 \\
\hline & Kepuasan_Pelanggan & .456 & .038 & .552 & 11.993 & .000 \\
\hline
\end{tabular}

a. Dependent Variable: Loyalitas_ Pelanggan

Pada tabel 11 coeffisients di atas menunjukkan besarnya pengaruh masingmasing variabel kausal terhadap Y2. Kolom beta $\beta$ menunjukkan besar pengaruh masing-masing pengaruh kausal. Pengaruh variabel X1 (kualitas layanan) $\beta$ sebesar 0.265 , variabel X3 (harapan pelanggan) $\beta$ sebesar 0.238 dan variabel Y1 (kepuasan pelanggan) $\beta$ sebesar 0.552. Pengaruh ketiga variabel tersebut adalah signifikan, karena kolom Sig lebih kecil dari nilai $\alpha(0,01)$.

\section{Uji Hipotesis}

Uji Hipotesis H1: Pengaruh kualitas layanan (X1) terhadap kepuasan pelanggan (Y1) hotel bujet di Bandung sebesar 0.146. dengan tingkat signifikansi $0.008<\alpha 0.01$, sehingga hipotesis nol ditolak dan hipotesis alternatif yang 
berbunyi "Kualitas layanan mempengaruhi langsung kepuasan pelanggan hotel bujet di Bandung" diterima kebenarannya.

Uji Hipotesis H2: Pengaruh tanggapan nilai (X2) terhadap kepuasan pelanggan (Y1) hotel bujet di Bandung sebesar 0.483 dengan tingkat signifikansi $0.000<\alpha 0.01$, sehingga hipotesis nol ditolak dan hipotesis alternatif yang berbunyi "Tanggapan nilai mempengaruhi langsung kepuasan pelanggan hotel bujet di Bandung" diterima kebenarannya.

Uji Hipotesis H3: Pengaruh harapan pelanggan (X3) terhadap kepuasan pelanggan (Y1) hotel bujet di Bandung sebesar 0.289 dengan tingkat signifikansi $0.000<\alpha 0.01$, sehingga hipotesis nol ditolak dan hipotesis alternatif yang berbunyi "harapan pelanggan mempengaruhi langsung kepuasan pelanggan hotel bujet di Bandung" diterima kebenarannya.

Uji Hipotesis H4: Pengaruh kualitas layanan (X1) terhadap loyalitas pelanggan hotel (Y2) bujet di Bandung sebesar 0.265 dengan tingkat signifikansi $0.000<a$ 0.01, sehingga hipotesis nol ditolak dan hipotesis alternatif yang berbunyi "harapan pelanggan mempengaruhi langsung kualitas loyalitas pelanggan hotel bujet di Bandung" diterima kebenarannya.

Uji Hipotesis H5: Pengaruh harapan pelanggan (X3) terhadap loyalitas pelanggan (Y2) hotel bujet di Bandung sebesar 0.238 dengan tingkat signifikansi $0.000<\alpha 0.01$, sehingga hipotesis nol ditolak dan hipotesis alternatif yang berbunyi "harapan pelanggan mempengaruhi langsung kepuasan pelanggan hotel bujet di Bandung" diterima kebenarannya.

Uji Hipotesis H6: Pengaruh kepuasan pelanggan (Y1) terhadap loyalitas pelanggan (Y2) hotel bujet di Bandung sebesar 0.552 dengan tingkat signifikansi $0.000<\alpha$ 0.01, sehingga hipotesis nol ditolak dan hipotesis alternatif yang berbunyi "kepuasan pelanggan mempengaruhi langsung kualitas loyalitas pelanggan hotel bujet di Bandung" diterima kebenarannya.

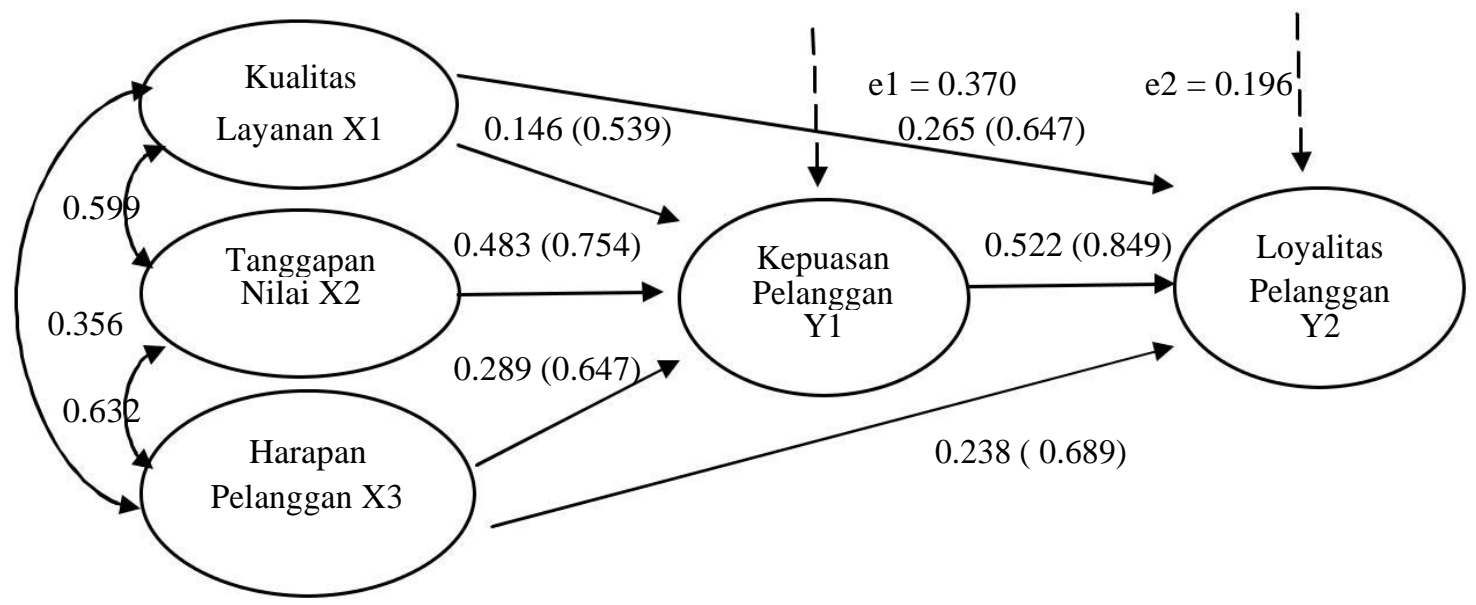

Gambar 4 Hasil Analisis Jalur 
Tabel 12 Pengaruh Langsung dan Tidak Langsung Analisis Jalur Model Rantai Kausal Pertama

\begin{tabular}{|c|c|c|c|c|c|}
\hline \multirow[b]{2}{*}{ Variabel } & \multirow[b]{2}{*}{$\begin{array}{c}\text { Pengaruh } \\
\text { Langsung } \\
(\%)\end{array}$} & \multicolumn{3}{|c|}{ Pengaruh Tidak Langsung } & \multirow[b]{2}{*}{$\mathbf{R}^{2}$} \\
\hline & & $\begin{array}{c}\text { Kualitas_ } \\
\text { Layanan } \\
\text { X1 (\%) } \\
\end{array}$ & $\begin{array}{c}\text { Tanggapan } \\
\text { _Nilai X2 } \\
(\%)\end{array}$ & $\begin{array}{c}\text { Harapan_ } \\
\text { Pelanggan } \\
\text { X3 (\%) }\end{array}$ & \\
\hline $\begin{array}{c}\text { Kualitas_Laya } \\
\text { nan (X1) }\end{array}$ & $\begin{array}{l}0.146 x \\
0.146= \\
2.13 \%\end{array}$ & - & $\begin{array}{c}0.146 x \\
0.599 x \\
0.483= \\
4.22 \%\end{array}$ & $\begin{array}{c}0.146 \mathrm{x} \\
0.356 \mathrm{x} \\
0.289= \\
1.50 \%\end{array}$ & $7.86 \%$ \\
\hline $\begin{array}{c}\text { Tanggapan_Ni } \\
\text { lai (X2) }\end{array}$ & $\begin{array}{l}0.483 x \\
0.483= \\
23.33 \%\end{array}$ & $\begin{array}{c}0.483 x \\
0.599 x \\
0.146 \\
4.22 \%\end{array}$ & - & $\begin{array}{c}0.483 x \\
0.632 x \\
0.289= \\
8.82 \%\end{array}$ & $36.37 \%$ \\
\hline $\begin{array}{c}\text { Harapan_Pela } \\
\text { nggan (X3) }\end{array}$ & $\begin{array}{l}0.289 x \\
0.289= \\
8.35 \%\end{array}$ & $\begin{array}{c}0.289 x \\
0.356 x \\
0.146= \\
1.50 \%\end{array}$ & $\begin{array}{c}0.289 x \\
0.632 x \\
0.483= \\
8.82 \%\end{array}$ & - & $18.68 \%$ \\
\hline $\mathrm{R}^{2}$ & & & & & $62.91 \%$ \\
\hline
\end{tabular}

Tabel 13 Pengaruh Langsung dan Tidak Langsung Analisis Jalur Model Rantai Kausal Kedua

\begin{tabular}{|c|c|c|c|c|c|}
\hline \multirow[b]{2}{*}{ Variabel } & \multirow[b]{2}{*}{$\begin{array}{c}\text { Pengaruh } \\
\text { Langsung } \\
\text { (\%) }\end{array}$} & \multicolumn{3}{|c|}{ Pengaruh Tidak Langsung } & \multirow[b]{2}{*}{$\mathbf{R}^{2}$} \\
\hline & & $\begin{array}{c}\text { Kualitas_ } \\
\text { Layanan } \\
\text { X1 (\%) }\end{array}$ & $\begin{array}{c}\text { Harapan_P } \\
\text { elanggan } \\
\text { X3 (\%) }\end{array}$ & $\begin{array}{c}\text { Kepuasan__ } \\
\text { Pelanggan } \\
\text { Y1 (\%) }\end{array}$ & \\
\hline $\begin{array}{c}\text { Kualitas_Laya } \\
\text { nan (X1) }\end{array}$ & $\begin{array}{c}0.265 x \\
0.265 \\
7.02 \%\end{array}$ & - & $\begin{array}{c}0.265 x \\
0.356 x \\
0.238 \\
2.25 \%\end{array}$ & $\begin{array}{c}0.265 x \\
0.539 x \\
0.552 \\
7.88 \%\end{array}$ & $17.2 \%$ \\
\hline \multirow[t]{2}{*}{$\begin{array}{c}\text { Harapan_Pela } \\
\text { nggan (X2) }\end{array}$} & $\begin{array}{l}0.238 x \\
0.238=\end{array}$ & $\begin{array}{c}0.238 x \\
0.356 x \\
0.265 \\
\end{array}$ & - & $\begin{array}{l}0.238 x \\
0.647 x \\
0.552=\end{array}$ & $16.4 \%$ \\
\hline & $5.66 \%$ & $2.25 \%$ & - & $8.50 \%$ & \\
\hline $\begin{array}{c}\text { Kepuasan_Pel } \\
\text { anggan (Y1) }\end{array}$ & $\begin{array}{c}0.552 x \\
0.552 \\
30.47 \% \\
\end{array}$ & $\begin{array}{c}0.552 x \\
0.539 x \\
0.265 \\
7.88 \% \\
\end{array}$ & $\begin{array}{c}0.238 x \\
0.647 x \\
0.552= \\
8.50 \%\end{array}$ & - & $46.9 \%$ \\
\hline$R^{2}$ & & & & & $80.4 \%$ \\
\hline
\end{tabular}




\section{PEMBAHASAN}

Hipotesis pertama yang mengatakan bahwa terdapat pengaruh langsung kualitas layanan (X1) terhadap kepuasan pelanggan (Y1) hotel bujet di Bandung terbukti kebenarannya. Dari tabel 8 di atas, koefisien variabel kualitas layanan sebesar 0.146 dengan nilai $\mathrm{p}$-value $0.008<0.01$ maka pengaruhnya signifikan. Variabel kualitas layanan menjadi salah satu variabel yang perlu dipertimbangkan dalam memberikan kepuasan pelanggan hotel bujet di Bandung.

Hipotesis keempat yang mengatakan bahwa terdapat pengaruh langsung kualitas layanan (X1) terhadap loyalitas pelanggan (Y2) hotel bujet di Bandung terbukti kebenarannya. Dari tabel $11 \mathrm{di}$ atas, koefisien variabel kualitas layanan sebesar 0.265 dengan nilai p-value $0.000<0.01$ maka pengaruhnya signifikan. Variabel kualitas layanan menjadi salah satu variabel yang perlu dipertimbangkan dalam memberikan loyalitas pelanggan hotel bujet di Bandung.

Dari hasil penelitian ini ternyata koefisien kualitas layanan berpengaruhnya paling kecil daripada tanggapan nilai dan harapan pelanggan. Koefisien $\beta$ tanggapan nilai dan harapan pelanggan lebih besar daripada kualitas layanan, pengelola hotel harus memperhatikan dimensi kualitas layanan agar meningkat. Penelitian ini tidak membahasdimensi. Dimensi kualitas layanan yang harus dikembangkan agar sesuai dengan harapan pelanggan yaitu : tangibles dari hotel bujet yang harus ditingkatkan dalam layanan kualitas yaitu fasilitas fisik hotel, kamar hotel, kebersihan, ukuran kamar, warna, penerangan ruang, kenyamanan ruangan, harum, suhu $\mathrm{AC}$, fasilitas, kenyamanan tempat tidur, pemanfaatan teknologi seperti internet, tampilan pegawai hotel (grooming), personil, dan materi komunikasi.

Dimensi reliability atau kehandalan dimana hotel bujet harus mampu memberikan pelayanan sesuai yang dijanjikan atau dipromosikan. Kualitas layanan harus sesuai dengan harapan pelanggan. Pegawai hotel dari front office, bell boy, dan semua lini harus berkinerja yang tepat waktu, layanan tanpa kesalahan, sikap simpatik dan dengan akurasi tinggi.

Dimensi responsiveness atas ketanggapan pegawai hotel bujet dengan tanggung jawabnya harus membantu dan memberikan layanan yang cepat (responsive), check-in, check-out, reservasi dan tepat kepada pelanggan, penyampaian informasi yang jelas sapaan. Tanggapan atas keluhan, bantuan dan order harus cepat, baik dan sempurna tanpa kesalahan. Sehingga konsumen tidak memberikan tanggapan yang negatif atas performa seorang pegawai, yang memberikan kesimpulan yang sama atas kinerja karyawan lainnya.

Dimensi assurance, atau jaminan dan kepastian dari pegawai hotel atas pengetahuan, sopan santun, dan kemampuan para pegawai hotel memberikan rasa percaya pelanggan kepada perusahaan. Pegawai hotel harus mempunyai cara berkomunikasi yang baik dengan konsumen atau pelanggan, memberikan rasa aman, sopan santun atas segala perilaku dan tindkannya. Selain itu kompetensi pegawai hotel harus selalu diasah melalui pelatihan-pelatihan.

Dimensi empathy dari pegawai hotel bujet berupa yang hati tulus dan bersifat individual atau pribadi yang diberikan kepada pelanggan. Pegawai hotel bujet harus diingatkan dan diarahkan agar selalu memahami keinginan dan 
kebutuhan konsumen secara spesifik agar konsumen atau pelanggan hotel merasa nyaman.

Hipotesis kedua terdapat pengaruh antara tanggapan nilai terhadap kepuasan pelanggan hotel bujet di Bandung. Hipotesis kedua H2: Tanggapan nilai mempengaruhi langsung kepuasan pelanggan hotel bujet di Bandung. Koefisien variabel tanggapan nilai sebesar 0.483 dengan nilai $p$-value $0.000<0.01$ maka ada pengaruh positif dan signifikan yang menolak hipotesis nol dan terima hipotesis H2. Variabel tanggapan nilai menjadi salah satu variabel yang perlu dipertimbangkan dalam memberikan kepuasan hotel bujet di Bandung. Koefisien $\beta$ tanggapan nilai mempunyai nilai tertinggi yang mempengaruhi kepuasan pelanggan. Dimensi tanggapan nilai yaitu nilai fungsi, nilai finansial, nilai sosial dan nilai psikologis harus diperhatikan pengelola hotel bujet di Bandung. Konsumen ataupun pelanggan menilai melali empat fungsi nlai bahwa hotel bujet di Bandung memberikan nilai lebih daripada kualitas layanan yang diberikan.

Hipotesis ketiga terdapat pengaruh langsung harapan pelanggan terhadap kepuasan pelanggan hotel bujet di Bandung terbukti kebenarannya. Dari tabel 8 di atas, koefisien variabel harapan pelanggan sebesar 0.289 dengan nilai $\mathrm{p}$-value $0.000<0.01$ maka pengaruhnya signifikan. Pihak manajerial hotel bujet di Bandung harus memperhatikan harapan pelanggan dari kualitas layanan harus sesuai atau bahkan melebihi apa yang diharapkan oleh pelanggan. Performa eksplisit, performa implisit, performa statis dan dinamis serta performa teknologi yang diharapkan oleh pelanggan sebaiknya ditingkatkan oleh pihak manajemen hotel.

Variabel harapan pelanggan menjadi salah satu variabel yang perlu dipertimbangkan dalam memberikan kepuasan hotel bujet di Bandung. Nilai pengaruh koefisien $\beta$ layanan kualitas mempunyai nilai lebih rendah daripada koefisien $\beta$ harapan pelanggan, artinya hotel bujet harus lebih meningkatkan kualitas layanannya agar harapan pelanggan dapat terpenuhi.

Hipotesis kelima terdapat pengaruh langsung harapan pelanggan terhadap loyalitas pelanggan hotel bujet di Bandung terbukti kebenarannya. Dari tabel 8 di atas, koefisien variabel harapan pelanggan sebesar 0.238 dengan nilai $\mathrm{p}$-value $0.000<0.01$ maka pengaruhnya signifikan. Pihak manajerial hotel bujet di Bandung harus memperhatikan harapan pelanggan agar seorang pengguna menjadi seorang pelanggan yang loyal dan pelannggan yang loyal terus dapat dipertahankan. Harapan pelanggan ini harus ditingkatkan pengaruhnya pada loyalitas pelannggan yaitu dengan memperhatikan dimensi harapan pelanggan.

Hipotesis keenam yang menyatakan bahwa kepuasan pelanggann mempengaruhi langsung loyalitas pelanggan hotel bujet di Bandung terbukti kebenarannya. Koefisien variabel kepuasan pelanggn sebesar 0.552 dengan nilai p-value $0.000<0.01$ maka ada pengaruh positif dan signifikan yang menolak hipotesis nol dan terima hipotesis H6. Loyalitas pelanggan dipengaruhi 55,2\% dari kepuasan pelanggan. Koefisien ini dapat ditingkatkan dari kualitas layanan, tanggapan nilai dan harapan pelanggan.

Selain pengaruh langsung sebagaimana dibahas di atas, terdapat pengaruh tidak langsung yaitu 3 (tiga) pengaruh tidak langsung yaitu pengaruh tidak langsung kualitas layanan (X1) pada loyalitas (Y2) melalui kepuasan pelanggan 
(Y1) sebesar 8,1\%, tanggapan nilai (X2) pada loyalitas (Y2) melalui kepuasan pelanggan (Y1) sebesar 26,7\% dan harapan pelanggan (X3) pada loyalitas (Y2) melalui kepuasan pelanggan (Y1) sebesar 11,6\%. Pengaruh tidak langsung ini harus menjadi perhatian manajemen hotel bahwa melalui kepuasaan pelanggan akan terjadi perubahan konsumen menjadi pelanggan karena konsumen merasa terpuaskan dengan pengalaman menggunakan layanan hotel bujet. Sikap berikutnya pelanggan akan loyal kepada hotel bujet dengan mempertimbangkan hotel bujet sebagai pilihan pertama, merekomendasikan dan memberi tahu kepada koleganya, menceritakan pengalaman positifnya, dan pelanggan akan kembali dan bertransaksi kembali menggunakan hotel bujet.

\section{SIMPULAN}

Hasil penelitian ini menunjukkan bahwa kualitas layanan mempengaruhi secara signifikan terhadap kepuasan dan loyalitas pelanggan hotel bujet di Bandung. Dimensi dari kualitas layanan yaitu tangility, realibility, responsiveness, assurance dan emphaty harus diperhatikan dan dikembangkan oleh hotel bujet di Bandung. Perhatian pada kualitas layanan harus menjadi perhatian utama dari manajer hotel agar kepuasan pelanggan lebih meningkat.

Pengaruh langsung yang signifikan antara tanggapan nilai dan kepuasan pelanggan berkaitan dengan tingginya level dari tanggapan nilai. Jika tanggapan nilai menurun maka kepuasan pelanggan akan menurun yang selanjutnya akan menurunkan loyalitas pelanggan.

Signifikan yang positif ditunjukkan antara variabel harapan pelanggan dengan kepuasan pelanggan. Semakin tinggi harapan atas layanan kualitas maka pelanggan akan semakin meningkat. Hotel bujet harus meningkatkan terus harapan pelanggan agar memberikan pengaruh positif pada industri pariwisata di kota Bandung.

Selain pengaruh langsung terdapat pengaruh tidak langsung kualitas layanan, tanggapan nilai dan harapan pelanggan terhadap loyalitas pelanggan melalui kepuasan pelanggan.

\section{SARAN}

Manajemen hotel haruslah mengadakan peningkatan kompetensi sumber daya manusianya melalui pelatihan kualitas layanan dari berbagai dimensi kualitas layanan. Supervisi terus menerus sehingga konsumen mendapatkan kualitas layanan lebih baik dan pelanggan akan kembali dan setia menggunakan jasa yang ditawarkan hotel bujet.

\section{DAFTAR PUSTAKA}

Bramson, Robert. (2005). Customer Loyalty 50. Prestasi Pustaka. 
Bramson, Robert. (2005). Customer Loyalty 50. Prestasi Pustaka.

Birgelen, M., Wetzels, M., and de Ruyter, K. (1997). Commitment In Service Relationships: An Empirical Test Of Its Antecedents And Consequences. Paper presented at the EMAC Conference Proceedings.

Bolton, R. N., and Drew, J. H. (1991). A Multistage Model Of Customers' Assessments Of Service Quality And Value. Journal of consumer research, 375-384.

Boulding, W., Kalra, A., Staelin, R., and Zeithaml, V. A. (1993). A Dynamic Process Model Of Service Quality: From Expectations To Behavioral Intentions. Journal of marketing research, 30(1), 7-27.

Fiorentino, A., (1995). Budget Hotes; Not Just Minor Hospitality Products. Tourism Management, 16 (6), 455-462.

Gilbert, D.C., Lockwood, A. (1990). Budget Hotels - The USA, France And UK Compared. Travel Tour. Anal. 3 (1), 19-35.

Gramer and Brown (2006). Customer loyalty as competitive advantage. Erlangga, Jakarta.

Hemmington, N., (2007). From Service To Experience: Understanding And Defining Thehospitality Business. Serv. Ind. Journal. 27 (6), 747-755.

Heskett, J. L., and Sasser, W. E. (2010). The Service Profit Chain: From Satisfaction To Ownership. Handbook of Service Science, Part 1, 19-29.

Hokanson, S., (1995) - The Deeper You Analyze The More You Satisfy Customersl, Marketing News, January 2, p. 16.

Kotler, P and Keller, K, (2012), -Marketing Managementll. $13^{\text {th }}$ edition, Prentice-Hall.

Kotler, P. Bowen, J.T., and Makens. J, (2014). Marketing for Hospitality and Tourism, 6th Ed, Prentice Hall.

Peter Doyle, (2009), Value - Based Marketing : Marketing Strategies for Corporate Growth and Shareholder Value, Wiley.

Parasuraman, A., Zeithaml, V. A., and Berry, L. L. (1985). A Conceptual Model Of Service Quality And Its Implications For Future Research. The Journal of Marketing, 41-50.

Parasuraman, A., V.A. Zeithmal and L.L. Berry, 1988. SERQUAL : A MultipleItem Scale For Measuring Consumer Perceptions Of Service Quality. Journal. Retail., 64(1); 12-40.

Parasuraman, A., Berry, L. L., and Zeithaml, V. A. (1991). Understanding Customer Expectations Of Service. Sloan Management Review, 32(3), 3948.

Patterson, P. G., and Spreng, R. A. (1997). Modelling The Relationship Between Perceived Value, Satisfaction And Repurchase Intentions In A BusinessTo-Business, Services Context: An Empirical Examination. International Journal of service Industry management, 8(5), 414-434.

Pitt, L. F., and Jeantrout, B. (1994). Management Of Customer Expectations In Service Firms: A Study And A Checklist. Service Industries Journal, 14(2), 170-189. 


\section{Tourism Scientific Journal}

Volume 2 Nomor 1 Desember 2016

Ruetz, D., Marvel, M. (2011). Budget Hotels: Low Cost Concepts In The US, Europe Andasia. In: Conrady, R., Buck, M. (Eds.), Trends and Issues in Global Tourism 2011. Springer, Verlag Berlin Heidelberg

Trihendradi. C. (2013). Analisis Data Statistik, Step by Step IBM SPSS 21. Penerbit Andi, Jogjakarta.

Zairi, M. (2000) "Managing customer satisfaction: a best practice perspective", The TQM Magazine, Vol. 12 (6), pp.389-494

Zhang, H.Q., Ren, L, Huawen, S., Xiao, Q., (2013b). What contributes to the success of Homm Inn in China? International Journal Hospitality Management. 33, 425 - 434 